\title{
RISK FACTORS FOR HOCK LESIONS OCCURRENCE IN DAIRY COWS
}

\author{
Toncho Penev ${ }^{1}$, Ivaylo Marinov², Dimo Dimov", \\ Zhivka Gergovska², Chonka Miteva ${ }^{1}$, Jurii Mitev
}

\begin{abstract}
${ }^{1}$ Department of Applied Ecology and Animal Hygiene, Faculty of Agriculture, Trakia University, 6000 Stara Zagora, Bulgaria ${ }^{2}$ Department of Animal Husbandry - Ruminants and Dairy Farming, Faculty of Agriculture, Trakia University, 6000 Stara Zagora, Bulgaria
\end{abstract}

To link to this article: https://doi.org/10.11118/actaun201967020415

Received: 7. 11. 2018, Accepted: 4. 2. 2019

To cite this article: PENEV TONCHO, MARINOV IVAYLO, DIMOV DIMO, GERGOVSKA ZHIVKA, MITEVA CHONKA, MITEV JURII. 2019. Risk Factors for Hock Lesions Occurrence in Dairy Cows. Acta Universitatis Agriculturae et Silviculturae Mendelianae Brunensis, 67(2): 415-423.

\begin{abstract}
The aim of the study was to investigate the risk factors for formation of hock lesions in dairy cattle farms with different housing system. The study included 508 Black-and-white Holstein-type cows from 14 dairy farms in different regions of Bulgaria. On cows a hock lesion assessment (scale 1 to 3 ) and body condition scoring (scale 1 to 5) were made. From the total number of cows, 231 cows (45.5\%) with score of 2 and 3 were reported, which clinical manifestation was from loss of hairs on the hock joint surface to swellings and wounds. A statistically significant effect of lactation period, body condition scores (BCS) and housing system on the hock assessment score was found. The least square means (LSM) for hock assessment score increased with the advancing of lactation period from 1.22 in cows to 60 days in milk (DIM) to 1.52 in cows after 120 DIM. The percentage of cows with BCS 3 and 3.5 was lower 1.5 to 2 times compared to cows with BCS 1.5. With the lowest mean hock assessment score (1.14), were the cows housed free group on a thick bedding. Tie-stall housing system occupied an intermediate position with respect to hock assessment, only $1.4 \%$ of cows were with a score of 3. The highest percentage of cows with varying degrees of hock lesions were reported in free-stall housing system with using of rubber mats for stall floors, $75.5 \%$ of the cows were with hock lesion assessment score 2 and 3 . This percentage was slightly lower when small amounts of straw were placed on the rubber mats.
\end{abstract}

Keywords: dairy cattle farming, hock lesions assessment, dairy cows welfare, housing system, BCS

\section{INTRODUCTION}

The hock lesions are widespread on dairy cattle farms in a number of countries - in the United Kingdom - 91.7\% (Potterton et al., 2011); Canada - $47 \%$ (Zaffino et al., 2014);
Norway - 61\%, (Kielland et al., 2009); United States - from 41 to $72.3 \%$ for the different states (von Keyserlingk et al., 2012) of the dairy cows are affected by this problem. In Europe, skin lesions in the hock area are so common that in some farms they reach up to $100 \%$ of the cows (Kielland et al., 
2009). The skin injuries in the hock joint area are an indicator which is also important for the welfare of the cows (Livesey et al., 2002). The presence of hock lesions was ranked with the highest category from nine studied "freedom from discomfort" factors from the welfare requirements (Angus et al., 2005). These lesions, apart from the cow welfare, are often associated with lameness and economic losses in the dairy sector (Kester et al., 2014). The lack of progress in reducing the incidence of these injuries is surprising, considering that they are relatively easy to repord (Potterton et al., 2011).

The factors associated with the appearance of these lesions can be presented in three groups: technological, organizational, and related to the animals themselves (Nash et al., 2016). Most often factors of technological and organizational nature are sharp, hard and abrasive lying surfaces (Livesey et al., 2002; Barrientos et al., 2013; de Vries et al., 2015), absence or insufficient quantity of bedding (Barrientos et al., 2013) and year-round indoors housing (Keil et al., 2006; Barrientos et al., 2013; de Vries et al., 2015). The probability for hock integument alterations such as hair loss, lesions or swellings decreased with increasing amount of grazing hours (Burow et al., 2013).

Factors associated with the animals most often are the lactation period (Busato et al., 2000; Kielland et al., 2009), age (Kielland et al., 2009; Potterton et al., 2011), body condition score (Busato et al., 2000; Lim et al., 2015) as well as various conformation disadvantages associated with the legs (Busato et al., 2000; Meyers 2012).

In recent years in our country, as in many other countries, there is a tendency for enlargement of dairy cattle farms and more widespread implementation of the free indoor housing, because this housing system gives greater opportunities for intensification of production, but also it provides animals with a greater opportunity of free choice and species-specific behavior. Not always the improvements in one aspect of the welfare of animals lead to an improvement of all others (von Keyserlingk et al., 2009). The free-stall barns sometimes expose cows to unwanted risks as solid concrete alleys covered with manure (Cook and Nordlund, 2009), and also inappropriate surface for lying in free-stalls associated with the high prevalence of lameness and leg injuries including skin injuries of the hock (Haskell et al., 2006; Fulwider et al., 2007; Lombard et al., 2010). Hock lesions are reported in both tied and free rearing cows (Araneda 2012; Brenninkmeyer et al., 2013; Nash et al., 2016).
The aim of the present study was to investigate the risk factors for the formation of hock lesions in dairy cattle farms with different housing system in Bulgaria.

\section{MATERIALS AND METHODS}

The study was conducted at 14 dairy cattle farms in different regions of the country. In all farms, Black-and-white Holstein-type cows were reared. Farms had different housing systems, respectively 4 with tie-stall, 4 with free group and 6 with free-stall housing system.

The buildings of the farms with tie-stall housing were old with floor of the beds covered with floor bricks, which surface was locally quite worn. In these farms straw was used for bedding as the quantity was $0.5-1 \mathrm{~kg}$ straw per stall every day after removing the polluted one. Cows spend most of the day in the yards, where only the alley in front of the feed bunk was concreted and the rest was earth floor. Dry cows were housed under the same conditions.

At the farms with free group housing in the resting area, cows were provided with thick straw bedding. Periodically, new bedding was spread (once a week). Twice a year the building was cleaned up the accumulated bedding and manure. Lactating and dry cows were housed under the same conditions.

In all farms with free-stall housing system, the stall floors were covered with rubber mats, without or with a minimal (less than $0.5 \mathrm{~kg}$ straw) amount of bedding. On farms that use bedding, once a week the back of the stall was cleaned and straw about $0.5 \mathrm{~kg}$ was spread on it. This was in relation to the quality of manure and its suitability for mechanized use later. During the dry period in all farms cows were reared free on deep straw bedding.

The total number of cows included in the study was 508, 145 in farms with tie-stall housing system, 124 with free group and 239 with free-stall housing system. Only lactating cows from first to third lactation were included in the study, respectively 220 on first, 190 on second and 98 on third lactation. Cows with bigger lactation number were not included because their smaller number, their unequal distribution by lactation and the presence of various additional age-related problems. The study included lactating cows up to about 150-180 DIM in free-stall and free group housing systems and cows in the same lactation period in tie-stall housing system. The distribution of cows by lactation period was respectively up 
to 60 DIM - 126, 61-120 DIM - 140 and after 121 DIM - 242 cows. From each farm from 30 to 50 cows depending on farm capacity were included. In the small farms all cows, that meet the above mentioned conditions were included (lactation number, lactation period), and in the larger - all cows that meet these conditions from the technological groups in first lactation period.

An assessment of the severity of lesions on hock joint on a 3-step scale was performed by one of the authors. On each animal the lateral surface of hock joints was assessed visually, using 3-step scale system developed by Cornell Cooperative Extension (Hock Assessment Chart for Cattle, Cornell Cooperative Extension). With score 1, cows without bald area and other changes in the hock joint were described. With score 2 were cows that had alopecia in the examined area without visible swellings and other changes, and with score 3 were assessed cows that had lack of hairs and swellings or other diseases, such as bursitis that can lead to discomfort, and possibly lameness (Fig. 1).

On the same cows a body condition scoring by a system proposed by Todorov and Mitev (1993) on a scale from 1 to 5 , with an accuracy of 0.5 points was performed.

Both scorings (of hocks and BCS) were performed simultaneously on all cows at a one-time visit to the farm.

For the basic statistical data processing MS Excel was used, and for obtaining the mean values, the errors and the analysis of variance, the corresponding STATISTICA modules of Stat Soft (Copyright 1990-1995 Microsoft Corp.).

To evaluate the influence of the factors on the values of hock assessment the following regression mixed model was used:

$\mathrm{Y}_{\mathrm{ijklmn}}=\mu+\mathrm{T}_{\mathrm{i}}+\mathrm{L}_{\mathrm{j}}+\mathrm{P}_{\mathrm{k}}+\mathrm{BCS}_{\mathrm{l}}+\mathrm{F}_{\mathrm{m}}+\mathrm{e}_{\mathrm{ijklmn}}$

Where:

$Y_{\text {ijklmn }}$ was the dependent variable (hock assessment); $\mu$ was the mean effect; $T_{i}$ was the fixed effect of housing system; $L_{\mathrm{j}}$ was the fixed effect of the number of lactation; $\mathrm{P}_{\mathrm{k}}$ was the fixed effect of the lactation period; $\mathrm{BCS}_{1}$ was the fixed effect of body condition score, $F_{m}$ was the random effect of the farm and $e_{i j k l m n}$ was the random residual effect.

By analysis of variance (ANOVA) for the model by classes of fixed factors the least square means (LSM) were obtained, representing the sums of the squares, calculated as a deviation from the mean value of the trait derived from the model.

\section{RESULTS AND DISCUSSION}

From a total of 508 cows reared in 14 dairy farms with different housing system, 231 cows (45.5\%) with score 2 and 3 were reported, with pathological changes that were expressed from loss of hairs on the hock joint surface to swellings and lesions. This percentage ranges from $7.8 \%$ to $80 \%$ for the different farms. The presence of cows with a score 3 varies in herds, from $0 \%$ to $22.9 \%$.
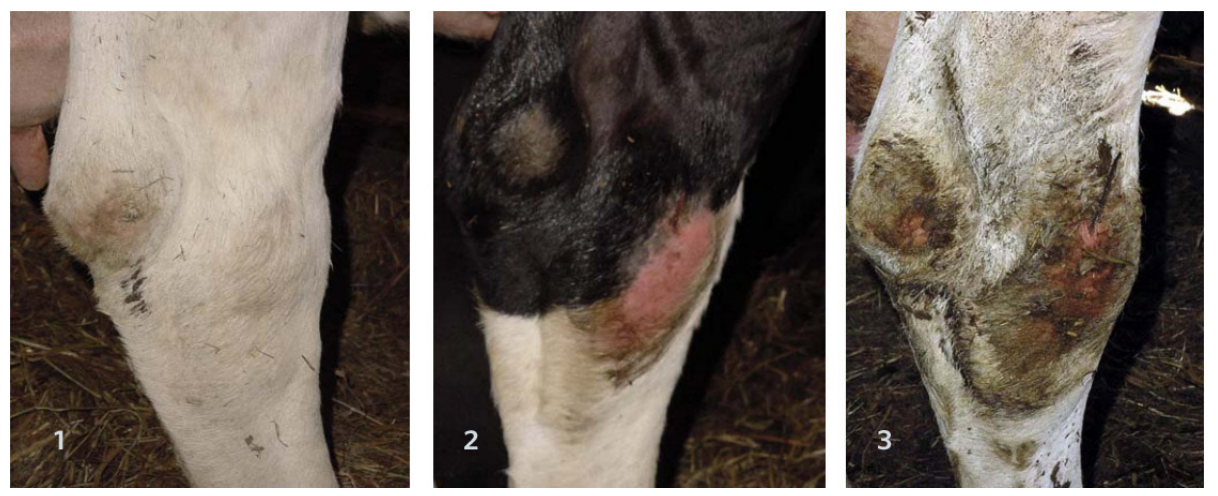

1: Hock assessment scale (adapted from Hock Assessment Chart for Cattle, Cornell Cooperative Extension, Cornell University)

I: Distribution of cows depending on hock assessment score in the studied dairy farms $(n=14)$

\begin{tabular}{ccccc}
\hline Indicators & $\begin{array}{c}\text { Number cows of } \\
\text { the total }\end{array}$ & $\begin{array}{c}\text { Average \% of the total } \\
\text { number of cows(508) }\end{array}$ & \multicolumn{2}{c}{ \% in the individual farms } \\
\hline Cows with score 1 & 277 & 54.5 & 20 & max \\
\hline Cows with score 2 & 205 & 40.4 & 5.9 & 71.4 \\
Cows with score 3 & 26 & 5.1 & 0 & 22.9 \\
\hline
\end{tabular}


Other studies also reported a considerable variation of hock lesions by herds. Brenninkmeyer et al. (2013) reported a mean farm prevalence of hock lesions (scabs, wounds, and swellings) of $50 \%$ from 0 to $100 \%$ in 105 dairy farms in Germany and Austria.

According to Meyers, (2012), if more than $5 \%$ of cows in the herd have a different lesion (alopecia, edema or ulceration), critical analysis and changes in cow comfort, hoof trimming and selection should be made. In our study, only 3 farms had less than $20 \%$ of hock lesions (score 2 and 3) and they all were with free group housing system.

Tab. II presents the results of analysis of variance for influence of controlled factors on the hock assessment score. On the score a significant effect of the lactation period ( $\mathrm{P}<0.001)$, BCS $(\mathrm{P}<0.05)$ and the housing system $(\mathrm{P}<0.001)$ was reported.

Fig. 2 shows the LS-mean hock assessment in cows with different lactation number obtained from the model. From the values presented, it is evident that there was a tendency for more lesions in cows with increasing number of lactations, although not significant. Cows in both types free housing systems (free stall and free group) with the exception of tie stall, during the dry period were housed in separate groups, mostly on thick straw bedding. During this period, most of hock damages that occurred during lactation were recovered. In our opinion, this might be the reason why no significant effect of number of lactation on the score was reported.

Weary and Taszkun (2000) reported that the presence and severity of hock lesions increased with the number of lactations, but other authors such as Araneda (2012) did not establish such relationship.

On the hock assessment score a significant effect of the lactation period was reported (Fig. 3).

Although the study covered cows up to and shortly after mid-lactation, a higher mean score for cows in a later lactation period was observed, and respectively, a larger number of cows with problems in the hock joint. This can be explained with more prolonged in the time contact of the hock skin with the floor in later lactation periods.

II: Analysis of variance for influence of controlled factors on the hock assessment

\begin{tabular}{l|c|c|c}
\hline \multicolumn{1}{c}{ Source of variation } & Degrees of freedom (n-1) & \multicolumn{2}{c}{ Hock assessment score } \\
\cline { 2 - 4 } & & MS & F P \\
\hline Total for the model & 11 & 3.234 & $11.18 * * *$ \\
\hline Number of lactation & 2 & 0.512 & $1.77 \mathrm{~ns}$ \\
\hline Lactation period & 2 & 3.239 & $11.20 * * *$ \\
\hline BCS & 4 & 0.812 & $2.81 *$ \\
\hline Technology & 2 & 7.198 & $24.89 * * *$ \\
\hline Farm & 1 & 0.339 & $1.17 \mathrm{~ns}$ \\
\hline Error & 496 & 0.289 & \\
\hline
\end{tabular}

- significance at $\mathrm{P}<0.05 ; * * *$ - significance at $\mathrm{P}<0.001 ; \mathrm{ns}$ - no significant effect

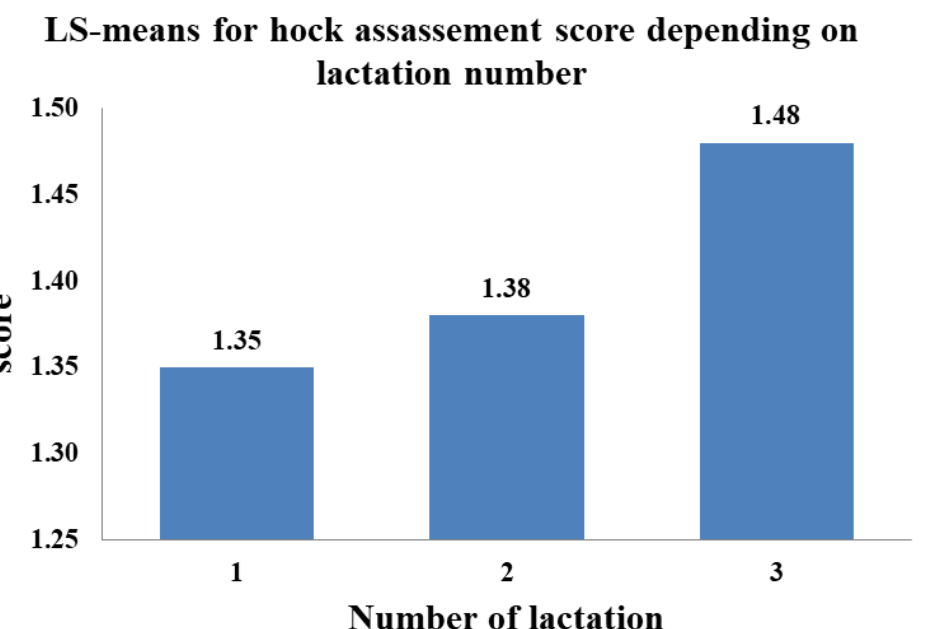

2: LS-means for hock assessment score depending on lactation number 
At the beginning of lactation for the first 2 months, the percentage of cows with no injury in the hock joint area was the highest - $68.2 \%$, only about $28 \%$ of cows had a different degree of injury and only $3.2 \%$ had more serious lesions - score 3, Tab. III. Half of the cows at a later stage of lactation (Table III), respectively 49.9 (61-120 DIM) and $50.2 \%$ (after 121 DIM), had no hock lesions.

From the second to the third period a higher percentage of cows with more serious damages ware reported a score of 3, respectively -4.3 and $6.6 \%$.

Mowbray et al. (2003) pointed that the loss of hair cover and skin lesions in hocks area in dairy cows could develop rapidly, within 6 weeks after returning from pasture in the free-stall barns. Weary and Taszkun, (2000) and Kielland et al. (2009), also pointed as a risky the period of lactation from $59^{\text {th }}$ day after calving to $60^{\text {th }}$ day before calving.

From the analysis of these two factors - number of lactation and lactation period, it can be seen that both the number and severity of hock lesions were higher percentage with the extension of the contact time with the resting surface.

Another factor that had a significant effect on the hock assessment was the body condition score (BCS). On Fig. 4. The LS-mean values for the impact of BCS on the hock assessment are presented.

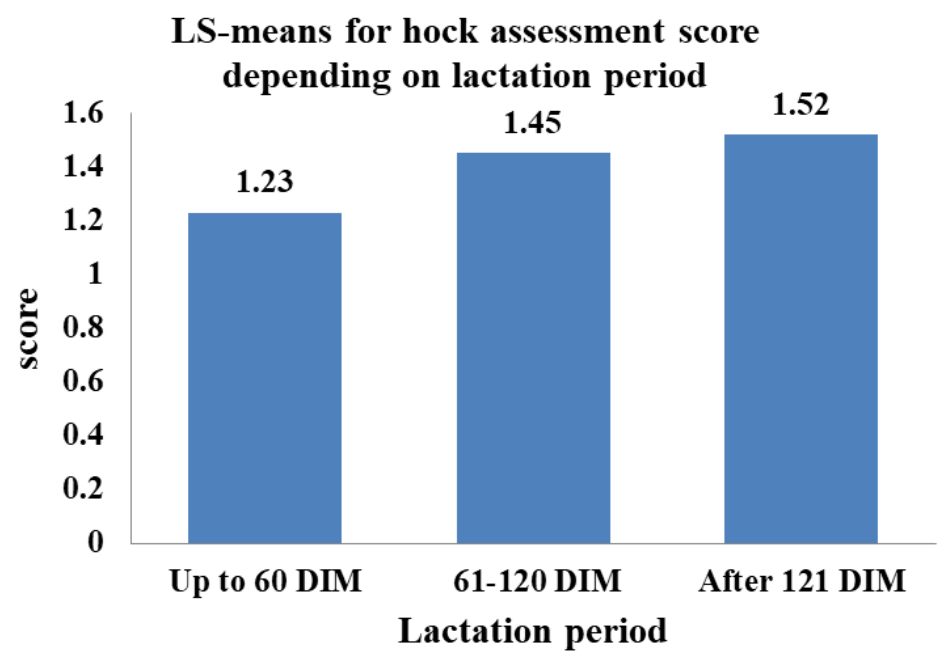

3: LS-means for hock assessment score depending on lactation period

III: Percentage of cows with varying score depending on lactation periods

\begin{tabular}{lccc}
\hline \multirow{2}{*}{ Lactation period } & \multicolumn{3}{c}{ Percentage of cows with score } \\
\cline { 2 - 4 } & $\mathbf{1}$ & $\mathbf{2}$ & $\mathbf{3}$ \\
\hline Up to 60 DIM & 68.2 & 28.6 & 3.2 \\
61-120 DIM & 49.9 & 45.9 & 4.3 \\
After 121 DIM & 50.2 & 43.2 & 6.6 \\
\hline
\end{tabular}

LS-means for hock assessement score depending on BCS

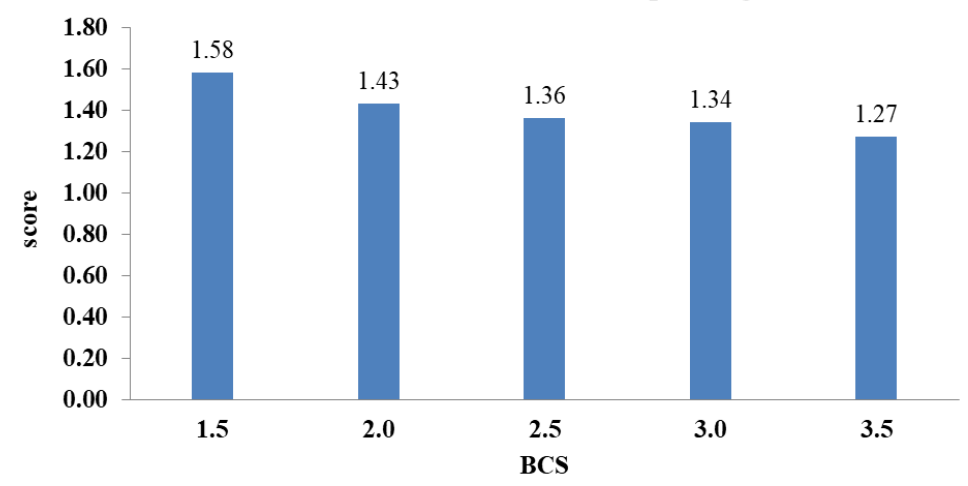

4: LS-means for hock assessment score depending on BCS 
Percentage of cows with different hock assessment score depending on BCS

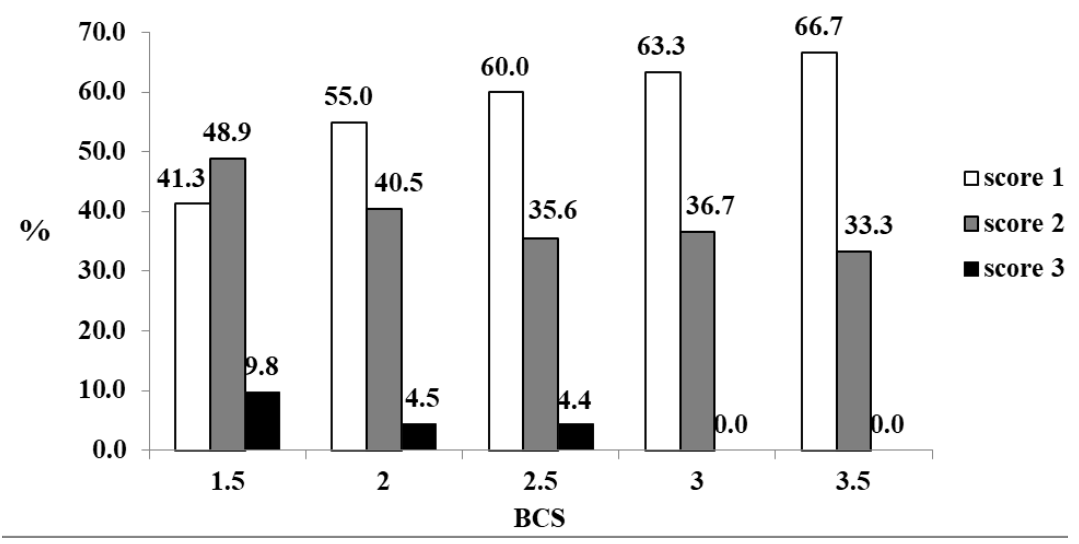

5: Percentage of cows with different hock assessment score depending on BCS

\section{LS-means for hock assessement score depending on} housing system

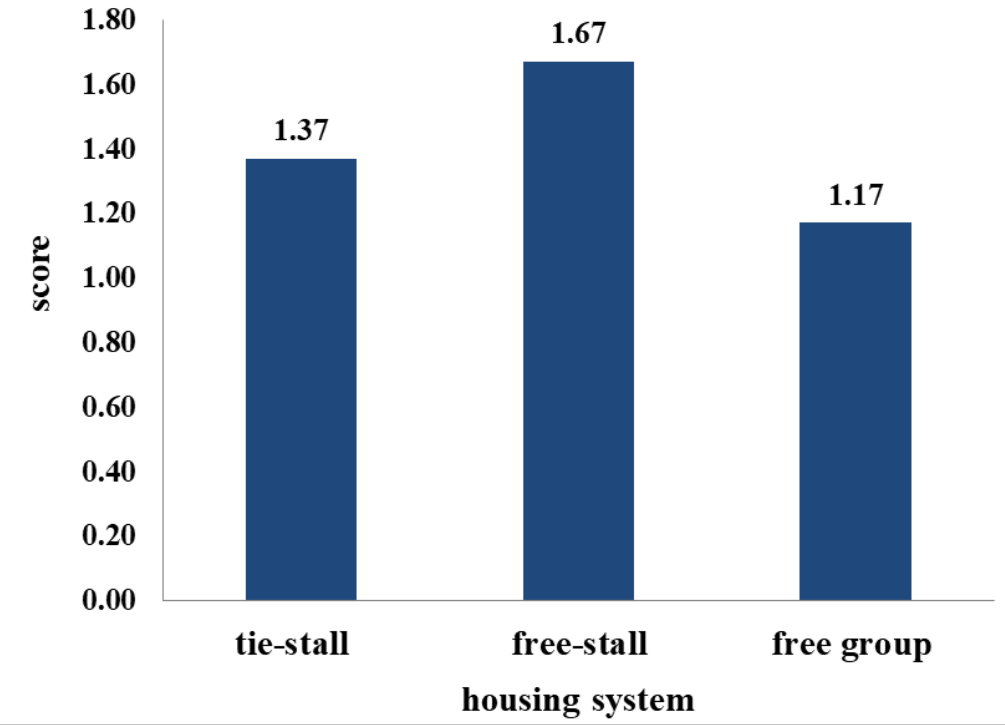

6: LS-means for hock assessment score depending on housing system

Percentage of cows with different hock assessment score depending on housing system

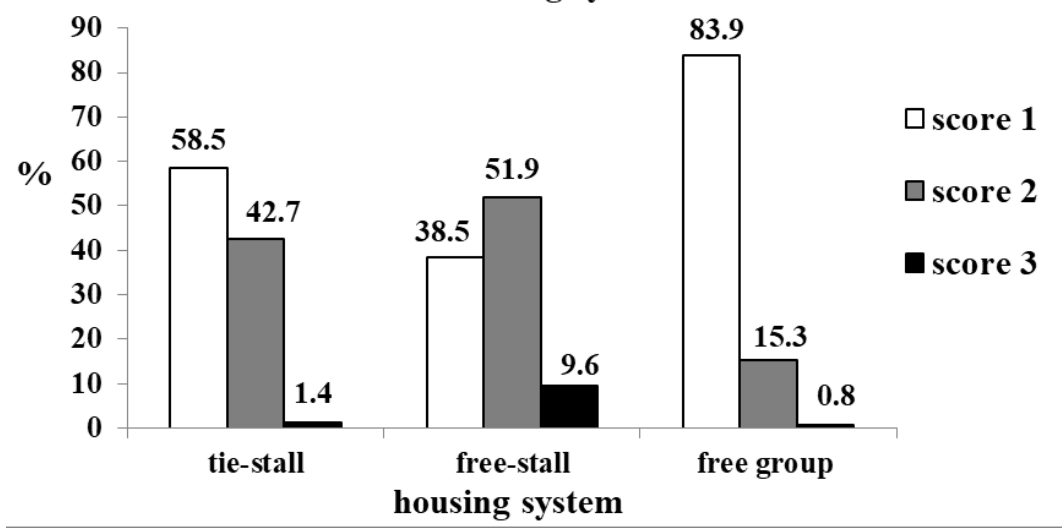

7: Percentage of cows with different hock assessment depending on housing system 
Variation of BCS in cows included in the study ranged from 1.5 to 3.5. In cows with lower BCS a tendency for a higher score was reported, Fig. 5

In addition to the higher mean scores, in cows with lower BCS, $58.7 \%$ of the cows had small to large hock lesions, Fig. 5. The percentage of cows with hock lesions was reduced 1.5 to 2 times in cows with BCS 3 and 3.5 compared to those with low BCS - 1.5. For cows with BCS 3 and 3.5 scores 3 were not reported. Our study confirms the results obtained by other authors (Kielland et al., 2009; Potterton et al., 2011), according to which the higher BCS leads to a decreasing the risk of hock lesions.

Lesions in the hock joint area are caused by friction of the joint surface with the surface of the floor or of the collision with the stall when cows lie down and stand up (Haskell et al., 2006). In cows with low BCS, there is a higher risk of lesions due to less fat in the hock joint area (Kester et al., 2014).

According to the authors, nutrition deficiency, overfeeding and metabolic disorders in liver function can lead to lack of minerals, vitamins and collagen, which is essential for tissue recovery, which in turn causes swelling. This swelling later affects tissue perfusion and with the time becomes necrosis (Bass and Phillips, 2007). There is also a hypothesis that weaker cows have less soft tissue with a protective role on their joints, so these cows are exposed to greater risk of injuries in this area of the body (Lim et al., 2015).

The housing system was a major factor that had a significant effect on the hock assessment. Fig. 6 presents LS-means of hock assessment scores depending on housing system.

The lowest LS-mean score - nearly one (1.17) were cows housed free group. At these farms thick straw bedding in the animal resting area was used. Possible contact of the rear legs surface with a hard floor was in the cases when they lie outside this area. With the highest LS-mean score were cows housed in free-stalls (1.67) (Fig. 6).

This was due to the fact that in these farms the stalls were covered with rubber mattresses without additional bedding and this causes the hock joint lesions. Penev et al. (2013) found a high adhesion with the dry surface of rubber mattresses, causing fraying the contact surfaces.

Fig. 7 shows the distribution of cows with different hock assessment score for the three housing systems. The highest percentage of cows without damage on the surface of the hock was at farms with free group housing with thick straw bedding $-83.9 \%$. At $15.3 \%$ of cows changes affecting mainly hair coat on the skin in the joint area (score 2) were established, and less than $1 \%$ (0.8) cases of more severe lesions (score 3 ).

Tied rearing occupied an intermediate position with regard to hock assessment score. A total of $44.1 \%$ of cows had some kind of hock damage (score 2 and 3), only 1.4\% were serious - score 3 . The straw bedding used on these farms to some extent prevents cows from heavier skin damage in the hock joint, mainly associated with the appearance of bald areas.

The highest percentage of cows with varying severity of injuries (score 2 and 3) were recorded in cows in free-stall housing system - 61.5\%. They also had the highest percentage of cows with heavier cases - swellings, lesions, etc. (Score 3) - 9.6\%. However, this percentage varies between farms ranging from 2.9 to $22.9 \%$, which can be explained by the different quantity of straw bedding used on rubber mattresses. A trend for a lower percentage and lower severity of injuries was observed at farms where a certain quantity of straw on rubber mats was spread.

Some authors point that hock injuries are common in free-stall barns, especially in those using rubber mattresses. In a study in 100 farms, Fulwider et al. (2007) reported that more than $80 \%$ of the cows reared in free-stalls with rubber mattresses had hock lesions and cows reared in stalls with a thick bedding or sand had little or no hock lesions.

According Husfeldt and Endres (2012) prevalence of hock lesions (score 2) and severe hock lesions (score 3) was lower in herds with bedding on a concrete stall floor (49.4\%; 6.4\%) than in herds with rubber mattresses on stall floor without bedding (67.3\%; 13.2\%). According to Chapinal et al. (2014) the prevalence of all hock traumas and severe hock injuries decrease in beds with thick bedding. This is due to the high adhesion of the rubber surfaces as mentioned before (Penev et al., 2013).

Solid surfaces such as concrete (Rushen et al., 2007) and compact rubber mats and mattresses (Wechsler et al., 2000; Kielland et al., 2010) are associated with the presence of hock and knee injuries. In contrast, the beds with a thick bedding of manure or sand, are associated with fewer and less severe hock injuries (Weary and Taszkun, 2000; Lombard et al., 2010; Husfeldt and Endres, 2012) compared to objects with poor bedding on concrete beds, rubber mats or mattresses. Keil et al. (2006) found that beds with straw bedding in Swiss farms have shown the best results in terms of hock lesions. 
Interest in the evaluation of welfare on farms around the world has grown over the past decade, in response to consumer demands for higher welfare standards (Fraser, 2003). Despite the high incidence of hock lesions and their relation to animal welfare there is a lack of understanding of the seriousness of this problem within the dairy farming. In Bulgaria such surveys are missing so far, but there are many farms, especially larger and new ones, where the problem of hock lesions is serious. More in depth research is needed, especially regarding the technological and managerial factors related to the increased risk of similar problems in dairy farms.

\section{CONCLUSION}

The results of the study showed that the basic prerequisite for the occurrence of hock lesions in dairy cows was the housing system and, in particular, the surface of beds (stalls) for lying. The lowest was the percentage of cows with hock lesions on farms with free group housing, on thick straw bedding. The highest percentage of cows with lesions - $75 \%$ with scores of 2 and 3, were reported in the farms with free-stall housing system and use of rubber mats in the stalls. There was a tendency for a lower percentage of cows with hock lesions and lesions with a lower severity in farms where on rubber mattresses a certain amount of straw was placed. On farms with tie-stall housing system 44,1\% of the cows had a different degree of manifestation of hock lesions (scores 2 and 3), with only $1.4 \%$ of them being severe - score 3. A tendency for more severe hock lesions in cows with a lower BCS and a higher mean hock lesion assessment score at a later lactation period was reported, respectively a larger number of cows with problems in the hock joint.

\section{REFERENCES}

ANGUS, L. J., BOWEN, H., GILL, L. A. S., KNOWLES, T. G. and BUTTERWORTH, A. 2005. The use of conjoint analysis to determine the importance of factors that affect on-farm welfare of the dairy cow. Anim. Welfare, 14: 203-213.

ARANEDA, A. K. 2012. Hock Injuries In Freestall Housed Dairy Cows. D.V.M., Universidad Austral de Chile.

BARRIENTOS, A. K., CHAPINAL, N., WEARY, D. M., GALO, E. and VON KEYSERLINGK, M. A. 2013. Herdlevel risk factors for hock injuries in freestall-housed dairy cows in the northeastern United States and California. J. Dairy Sci., 96: 3758-3765.

BASS, M. J. and PHILLIPS, L. G. 2007. Pressure sores. Curr. Probl. Surg, 44: 101-143.

BRANNINKMEYER, C., DIPPEL, S., BRINKMANN, J., MARCH, S., WINCKLER, C. and KNIERIM, U. 2013. Hock lesion epidemiology in cubicle housed dairy cows across two breeds, farming systems and countries. Preventive Veterinary Medicine, 109: 236-245.

BUROW, E., THOMSEN, P. T., ROUSING, T. and SǿRENSEN, J. T. 2013. Daily grazing time as a risk factor for alterations at the hock joint integument in dairy cows. Animal, 7(1): 160-166.

BUSATO, A., TRACHSEL, P. and BLUM, J. W. 2000. Frequency of traumatic cow injuries in relation to housing systems in Swiss organic dairy herds. J. Vet. Med. A Physiol. Pathol. Clin. Med., 47: 221-229.

CHAPINAL, N., LIANG, Y., WEARY, D. M., WANG, Y. and VON KEYSERLINGK, M. A. 2014. Risk factors for lameness and hock injuries in Holstein herds in China. J Dairy Sci., 97(7): 4309-4316.

COOK, N. B. and NORDLUND, K. V. 2009. The influence of the environment on dairy cow behavior, claw health and herd lameness dynamics. Vet. J., 179: 360-369.

DE VRIES, M., BOKKERS, E. A., VAN REENEN, C. G., ENGEL, B., VAN SCHAIK, G., DIJKSTRA, T. and DE BOER, I. J. 2015. Housing and management factors associated with indicators of dairy cattle welfare. Prev. Vet. Med., 118: 80-92.

FRASER, D. 2003. Assessing Animal Welfare at the Farm and Group Level: The Interplay of Science and Values. Animal Welfare, 12: 433-443.

FULWIDER, W. K., GRANDIN, T., GARRICK, D. J., ENGLE, T. E., LAMM, W. D., DALSTED, N. L. and ROLLIN, B. E. 2007. Influence of free-stall base on tarsal joint lesions and hygiene in dairy cows. J. Dairy Sci., 90: 3559-3566.

HASKELL, M. J., RENNIE, L. J., BOWELL, V. A., BELL, M. J. and LAWRENCE, A. B. 2006. Housing system, milk production, and zero-grazing effects on lameness and leg injury in dairy cows. J. Dairy Sci., 89: 4259-4266. 
HUSFELDT, A. W. and ENDRES, M. I. 2012. Association between stall surface and some animal welfare measurements in freestall dairy herds using recycled manure solids for bedding. J. Dairy Sci., 95(10): 5626-5634.

KEIL, N. M., WIEDERKEHR, T. U., FRIEDLI, K. and WECHSLER, B. 2006. Effects of frequency and duration of outdoor exercise on the prevalence of hock lesions in tied Swiss dairy cows. Prev. Vet. Med., 74: 142-153.

KESTER, E., HOZHAUER, M. and FRANKENA, K. 2014. A descriptive review of the prevalence and risk factors of hock lesions in dairy cows. The Veterinary Journal, 202: 222-228.

KIELLAND, C., BǾE, K. E., ZANELLA, A. J. and ØSTERAS, O. 2010. Risk factors for skin lesions on the necks of Norwegian dairy cows. J. Dairy Sci., 93: 3979-89.

KIELLAND, C., RUUD, L. E., ZANELLA, A. J. and ØSTERAS O. 2009. Prevalence and risk factors for skin lesions on legs of dairy cattle housed in freestalls in Norway. J. Dairy Sci., 92: 5487-5496.

LiM, P. Y., HUXLEY, J. N., GREEN, M. J., OTHMAN, A. R., POTTERTON, S. L., BRIGNELL, C. J. and KALER, J. 2015. Area of hock hair loss in dairy cows: Risk factors and correlation with a categorical scale. Vet. J., 203: 205-210.

LIVESEY, C. T., MARSH, C., METCALF, J. A. and LAVEN, R.A. 2002. Hock injuries in cattle kept in straw yards or cubicles with rubber mats or mattresses. Vet. Rec., 150: 677-679.

LOMBARD, J. E., TUCKER, C. B., VON KeYSERLINGK, M. A. G., KOPRAL, C. A. and WEARY, D. M. 2010. Associations between cow hygiene, hock injuries, and free stall usage on US dairy farms. J. Dairy Sci., 93: 4668-4676.

MEYERS, C. 2012. Dairy Cow Hock Lesions. Cow Tales. [Online]. Available at: http://cowdocscowtales.blogspot. com/2012/07/dairy-cow-hock-lesions.html

MOWBRAY, L., VITTIE, T. and WEARY, D. M. 2003. Hock lesions and free-stall design: effects of stall surface. In: Proc. of the Fifth International Dairy Housing Conference. St. Joseph, MI: American Society of Agricultural Engineers, pp. 288-295

NASH, C. G. R., KELTON, D. F., DE VRIES, T. J., VASSEUR, E., COE, J., ZAFFINO, HEYERHOFF, J. C., BOUFFARD, V., PELLERIN, D., RUSHEN, J., DE PASSILLE, A. M. and HALEY, D. B. 2016. Prevalence of and risk factors for hock and knee injuries on dairy cows in tiestall housing in Canada. J. Dairy Sci., 99: 1-13.

PENEV, T., MITEVA, C., DIMOVA, V., ROYDEV, R., MITEV, J. and MANOLOV, Z. 2013. Assessing frictional properties of rubber floors in free housing systems for dairy cows. Trakia Journal of Sciences, 2: 197-204.

POTTERTON, S. L., GREEN, M. J., MiLlAR, K. M., BRIGNELL, C. J., HARRIS, J., WHAY, H. R. and HUXLEY, J. N. 2011. Prevalence and characterisation of, and producers' attitudes towards, hock lesions in UK dairy cattle. Vet. Rec., 169: 634-647.

RUSHEN, J., HALEY, D. and DE PASSILLE, A. M. 2007. Effect of softer flooring in tie stalls on resting behaviour and leg injuries of lactating cows. J. Dairy Sci., 90: 3647-3651.

TODOROV, N. and MITEV, J. 1993. Cattle body condition score. Stara Zagora: MIT.

VON KEYSERLINGK, M. A. G., BARRIENTOS, A., ITO, K., GALO, E. AND WEARY, D. M. 2012. Benchmarking cow comfort on North American freestall dairies: Lameness, leg injuries, lying time, facility design and management, for high producing Holstein dairy cows. J. Dairy Sci., 95: 7399-7408.

VON KEYSERLINGK, M. A. G., RUSHEN, J., DE PASSILLE, A. M. and WEARY, D. M. 2009. Invited review: The welfare of dairy cattle-key concepts and the role of science. J. Dairy Sci., 92: 4101-4111.

WEARY, D. M. and TASZKUN, I. 2000. Hock lesions and free-stall design. J. Dairy Sci., 83: 697-702.

WECHSLER, B., SCHAUB, J., FRIEDLI, K. and HAUSER, R. 2000. Behaviour and leg injuries in dairy cows kept in cubicle systems with straw bedding or soft lying mats. Appl. Anim. Behav. Sci., 69: 189-197.

ZAFFINO HEYERHOFF, J. C., LEBLANC, S. J., DE VRIES, T. J., NASH, C. G., GIBBONS, J. and ORSEL, K. 2014. Prevalence of and factors associated with hock, knee, and neck injuries on dairy cows in freestall housing in Canada. J. Dairy Sci., 97: 173-184.

Toncho Penev: tonchopenev@abv.bg 